\title{
Nesting activities of Green turtles (Chelonia mydas) on the beaches of Zabargad Island, southern Egyptian Red Sea
}

\author{
Islam El-Sadek ${ }^{1}$; Mohammed I. Ahmed ${ }^{2}$; Maher A. Aamer ${ }^{2}$; Agnese Mancini ${ }^{3}$ \\ and Mahmoud H. Hanafy ${ }^{2}$ \\ 1- Marine Park Authorities of the Red Sea, EEAA, Egypt. \\ 2- Marine Science Department, Suez Canal University, Egypt. \\ 3- Hurghada Environmental Protection Association, Egypt.
}

\section{ABSTRACT}

Nesting of green turtles Chelonia mydas on the most valuable nesting of Zabaragad Island beaches were studied during the period between 2009 and 2014. On annual basis, and during the peak of the nesting season (mid of July), the nesting beaches on Zabargad Island were surveyed to estimate dimensions of female tracks, nests and female sizes and numbers of female tracks and true and false nests per night. Based on the model (software R) created by Girondot et al. (2012), the total numbers of tracks per season were estimated, consequently total numbers of tracks, false and true nests, and total numbers of nested females per nesting season were calculated annually. It was obvious that there is a clear trend of steadily increasing of green turtle nesting activities on the island during the study period. The numbers of female emergences per night have been estimated as 16.7, 11.3, 12.7, 17.0 and 22.7, in 2009, 2010, 2012, 2013 and 2014. Same trend was noticed for counts of true nests, being 1.7, 1.3, 3.4, 3.0 and 10 nest/night and total calculated annual tracks, being 1222.4, $790.3,989.24,2141.3$, and 1851.8 tracks, respectively. In total, the total estimates of nested females on Zabaraged Island ranged between 37 and 326 females per year during the study period between 2009 and 2014.

Keywords: Chelonia mydas, Green turtle, Red Sea, Zabaragad Island, nesting season, conservation, Egypt.

\section{INTRODUCTION}

Few studies on marine turtles have been done in Egypt or even in the whole Red Sea. Fraizer and Sales (1984) indicated that only five species are present in the Red Sea; the green turtle (Chelonia mydas), the hawksbill (Eretmochelys imbricata), the loggerhead (Caretta caretta), the olive-ridley turtle (Lepidochelys olivacea) and the leatherback turtle (Dermochelys coriacea). Chelonia mydas and Eretmochelys imbricata are the common species know to nest and feed in the Egyptian coast of the Red Sea (Anderson, 1898; Ross and Barwani, 1982; Frazier and Sales, 1984; Bertram and Evans, 1987; Hanafy, 2012). Miller (1997) reported that marine turtles in the Egyptian Red Sea are low in density and widespread nesting on the entire coast line and offshore island. The highly estimation for nesting population along the Egyptian Red Sea Coast was 1,500 nesting females (Hanafy, 2012).

Zabargad Island is known to be one of the most important nesting site for green turtles in the Red Sea (Hanafy, 2012,; Attum et al., 2014); Zabargad Island is in the territorial water of Egypt and located in the boundaries of the protected area and subjected to military control that limit visitor access, while all of that offer protection as result are of the remoteness (Hanafy, 2012; Attumet al., 2014), Islands are known to be important nesting habitats for sea turtles and other wildlife because offshore 
beaches are believed to have fewer natural predators and less anthropogenic disturbance that lost in the mainland nesting sites as result of their isolation (Attum, 2014). Decline nesting in the mainland of the Egyptian coast line was a result of rapid growing beachfront, development recreational use and anthropogenic disturbance (Hanafy, 2012).

Green turtles are endangered species according to the Red list of IUCN and have many natural and anthropogenic threats (Godley et al., 2008; IUCN, 2010) which includes delayed in maturation age, ontogenetic habitat use and long distance for migration that make them vulnerable to predators and lost in the sea (Musick and Limpus, 1997; Godley et al., 2008; Seminoff et al., 2008). In addition, the habitat of a sandy beach that used as nesting grounds and sea grass beds that used as feeding grounds are commonly degraded and its availability is getting decrease as a result of anthropogenic disturbances (Short et al., 2011). Green turtles populations are known to be declined worldwide by 37-61\% over the last 141 years (Seminoff, 2002). Protected areas in Egypt have challenges as a result of many challenges, such as pollution, fast grouning for coastal development, illegal fishing, and turtle bycatch which is not well known due to lack of studies (Frazier and Salas, 1984, Rouphaelet al., 2013). Inshore nesting habitats for marine turtle in the Egyptian coast of the Red Sea have degraded and destroyed according to development (Hanafy, 2012), while the offshore nesting habitats are still slightly protected but degraded closely according to some activities that reach the island (tourism and fishing).

The Red Sea is known to host some green turtle nesting sites; the most important ones being located in Saudia Arabia, Djibuti, Sudan and Egypt. Green turtle population in the Red Sea is estimated to be around 450 nesting females per year (excluding Eritrea for which data are not available; PERSGA/GEF, 2004). Few studies area available about green turtles on their nesting sites in Egypt, therefore the main aim of this work is to estimate the abundance of green turtle nesting population on Zabargadisland using standardized methodsof data collection.

\section{MATERIALS AND METHODS}

\section{Study site:}

Zabargad Island is a small island that is a part of the Gebel Elba Protected Areas. It is located in the Southern Egyptian Red Sea, approximately 37 nautical miles from the coastline. The island is mostly rocky but on the southern side there is a sandy beach of approximately $2.5 \mathrm{~km}$ long that is used by green turtles as the most valuable nesting site and another rocky beached intruppted by patchly sandy beach on the eastern side of approximately $1.5 \mathrm{~km}$ (only few tracks: $2-3$ ).Access to the island is forbidden at present but there are some activities going-on in and around the island that can be classified as legal diving and fishing activities around the island with most important mooring sites being located in front of the nesting beach by pleasure diving boats; and illegal activities (mainly access of fishermen and divers to the island where few incidents for collecting turtles and turtle eggs were reported. (Fig. 1)

\section{Methods:}

Surveys of nesting beaches are often used to assess the status of marine turtle populations (Schroeder and Murphy, 1999). These utilize the fact that each time a female turtle emerges from the water to attempt nesting (a "nesting activity"), it creates a distinctive set of tracks on the sand. To study the level and success of the green turtles nesting on Zabargad Island, the sand beach was surveyed during the nesting peak (July-August) in 2009, 2010, 2012, 2013 and 2014. 


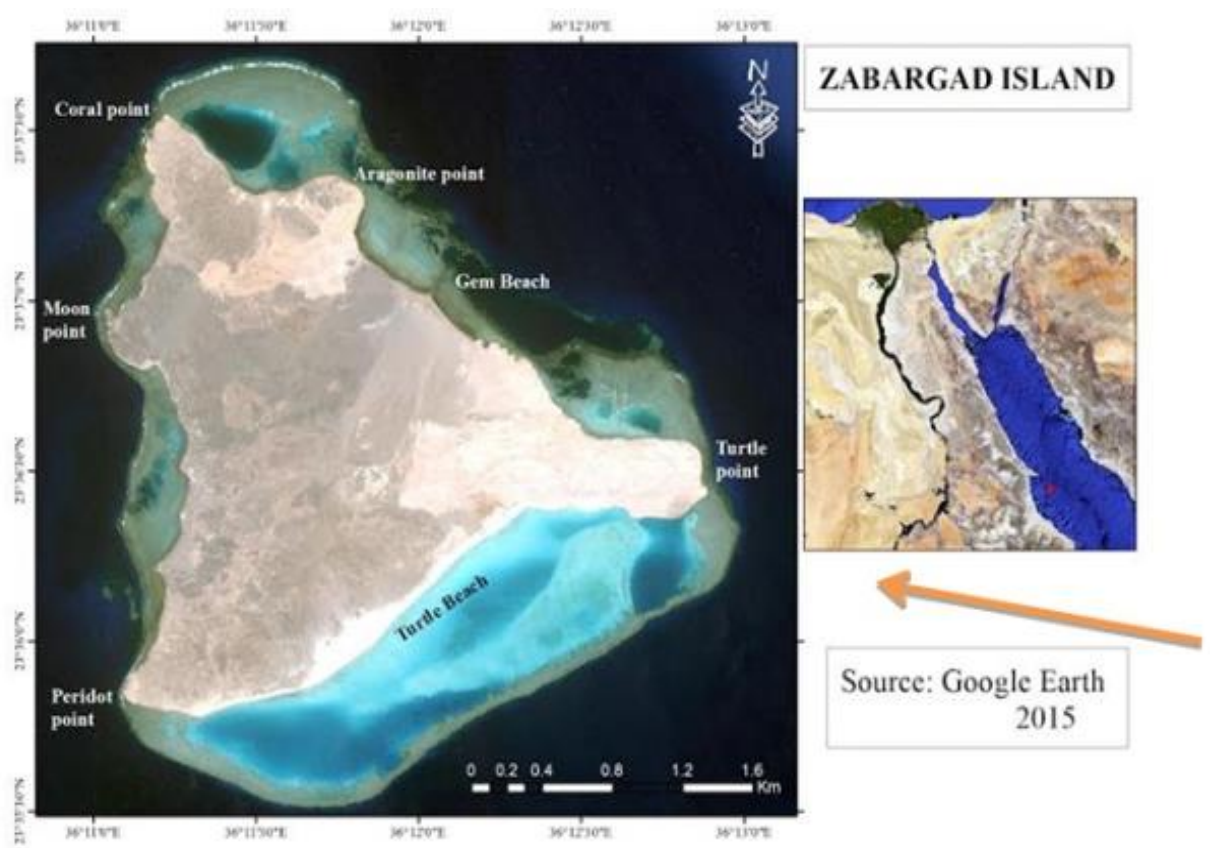

Fig. 1: Geographic map for Zabargad Island (Google earth, 2015).

Nesting activities of marine turtles were determined based on presence of crawls or tracks on the surveyed beach. Turtle tracks were classified into true or false tracks. The true one is defined as the track left by a female turtle that has ascended a beach and laid eggs. The false is defined as the track left by a female turtle that ascended a beach without laying eggs. During the present study, tracks as indicator for nesting activities were classified into two categories: true tracks (T), made by female emerged and crawled on the beach, built nest and laid eggs; false track (F), made by female emerged, crawled on the beach, but did not lay eggs even built or did not built a nest (Schroeder and Murphy, 1999).

During the nesting peak (July-August) of 2009, 2010, 2013 and 2014 (3 nights) and of 2012, (10 nights), nesing beaches on Zabargad Island were surveyed to determine number of tracks, true and false nests, nest and track dimensions and nesting success as number of true nests divided by the total number of tracks. Based on the model (software R) created by Girondot et al. (2012), the total numbers of tracks per season were calculated. Consequently total numbers of tracks, false and true nests, and total numbers of nested females per nesting season were estimated annually.

\section{RESULTS AND DISCUSSION}

Nesting success and density for green turtles on Zabargad Island's beaches were estimated annually for 5 years. The nesting intensities/level on the beaches of Zabargad Island were estimated as total numbers of female emergences on the beaches, true and false tracks and number of emergencies /night during the peaks of the nesting season of 2009, 2010, 2012, 2013 and 2014.

The number of female emergences per night was recorded for 3 following nights in nesting peaks of 2009, 2010, 2013 and 2014, and for 10 nights in the nesting peak of 2012. The total recorded emergences were 50, 34, 51 and 68 emergences per 3 
nights in 2009, 2010, 2013 and 2014, respectively, as well as 127 emergences per 10 nights in 2012, 16.7, 11.3, 12.7, 17.0 and 22.7 emergences per night in 2009, 2010, 2012, 2013 and 2014, respectively. The number of female emergencies per night seemed to be increased with years. Same trend was noticed for counts of true nests. In contrast, false nest counts seemed to be decreased with years. The emergences/night was gradually increased by years and recorded the lowest number in nesting peak of 2010 (11.3 emerge/night) and gradually increased to reach maximum record in the nesting peak of 2014, being 22.7 emerge/night (Fig. 2).

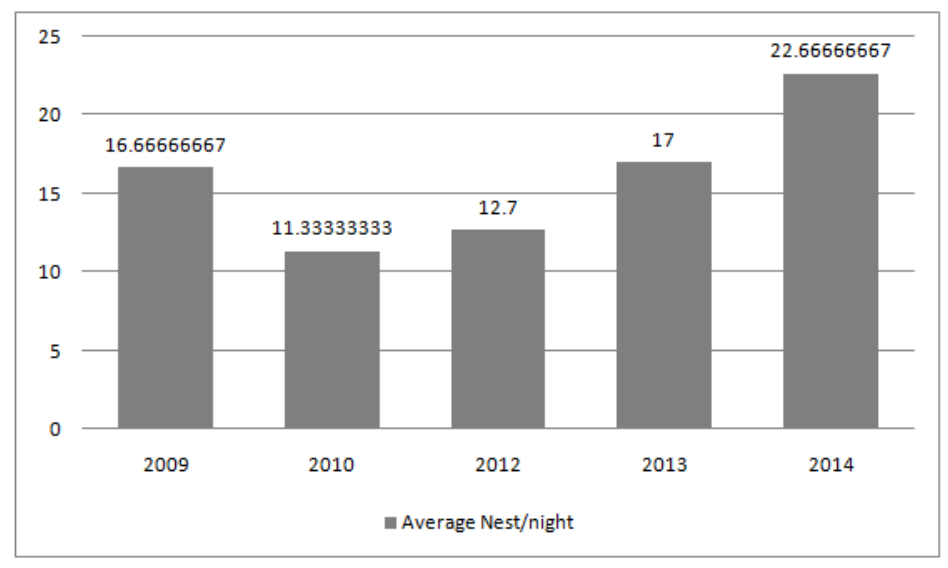

Fig. 2: The numbers of emergencies per nights recorded in the peak seasons of the study years of 2009, 2010, 2012, 2013 and 2014 on the main nesting beach of the Zabarged Island

\begin{tabular}{|l|l|l|l|l|l|}
\hline \multicolumn{1}{|c|}{ Parameter } & \multicolumn{1}{|c|}{$\mathbf{2 0 0 9}$} & \multicolumn{1}{c|}{$\mathbf{2 0 1 0}$} & \multicolumn{1}{c|}{$\mathbf{2 0 1 2}$} & \multicolumn{1}{c|}{$\mathbf{2 0 1 3}$} & \multicolumn{1}{c|}{$\mathbf{2 0 1 4}$} \\
\hline T & 5 & 4 & 34 & 15 & 30 \\
\hline F & 45 & 30 & 93 & 36 & 38 \\
\hline No. of nights & 3 & 3 & 10 & 3 & 3 \\
\hline Date of sighting & $2-4 / 8 / 2009$ & $25-27 / 7 / 2010$ & $30 / 7-8 / 8 / 2012$ & $24-26 / 7 / 2013$ & $9-11 / 8 / 2014$ \\
\hline Average Nest/night & 16.66667 & 11.33333 & 12.7 & 17 & 22.66667 \\
\hline No. of T /night & 1.7 & 1.3 & 3.4 & 3.0 & 10 \\
\hline
\end{tabular}

Table 1: Total numbers of emergences, emergencies/night, true (T) and false (F) nests and survey periods during the study years of 2009, 2010, 2012, 2013 and 2014, T= true nest, $F=$ False nest.

The number of true nests recorded per night increased gradually with years, being 1.7, 1.3, 3.4, 3.0 and 10 for nesting peaks of 2009, 2010, 2012, 2013 and 2014, respectively (Table 1). The percentage of true nest occurrence to the total number of emergences found to be increased gradually from $10 \%$ in 2009 to reach more than $44 \%$ in 2014 (Fig. 3).

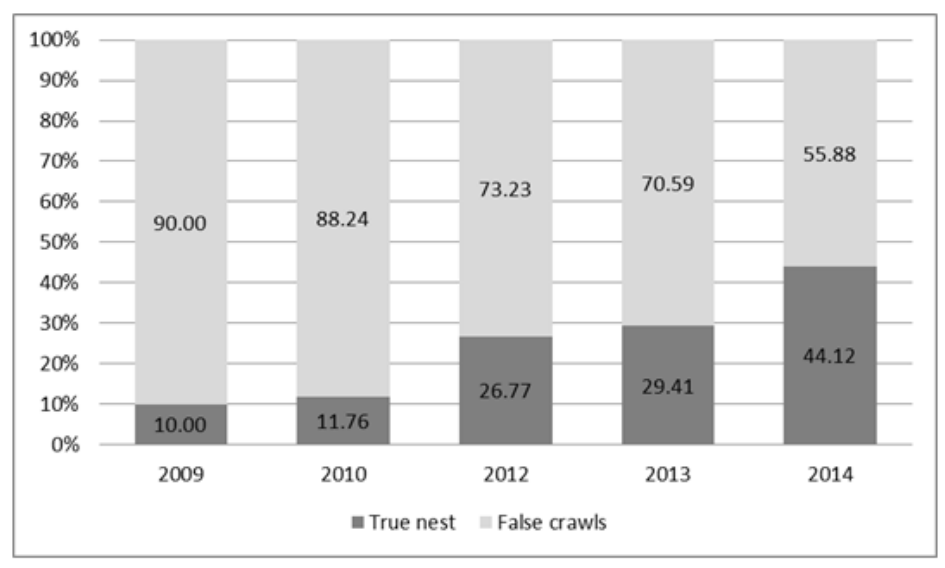


Fig. 3: Percentage of occurrence of the true nests (T) and false crawls (F) to the total emergences per night recorded during the nesting peaks of 2009, 2010, 2012, 2013 and 2014.

According to the model created by Girondotet al. (2012),, total estimation of $1222.4 \pm 188.9$ tracks were determined in $2009,790.3 \pm 284.4$ tracks in $2010,989.24$ \pm 259.7 tracks in $2012,2141.3 \pm 303.7$ tracks in 2013 and $1851.8 \pm 303$ tracks in 2014, as shown in Fig. 4.
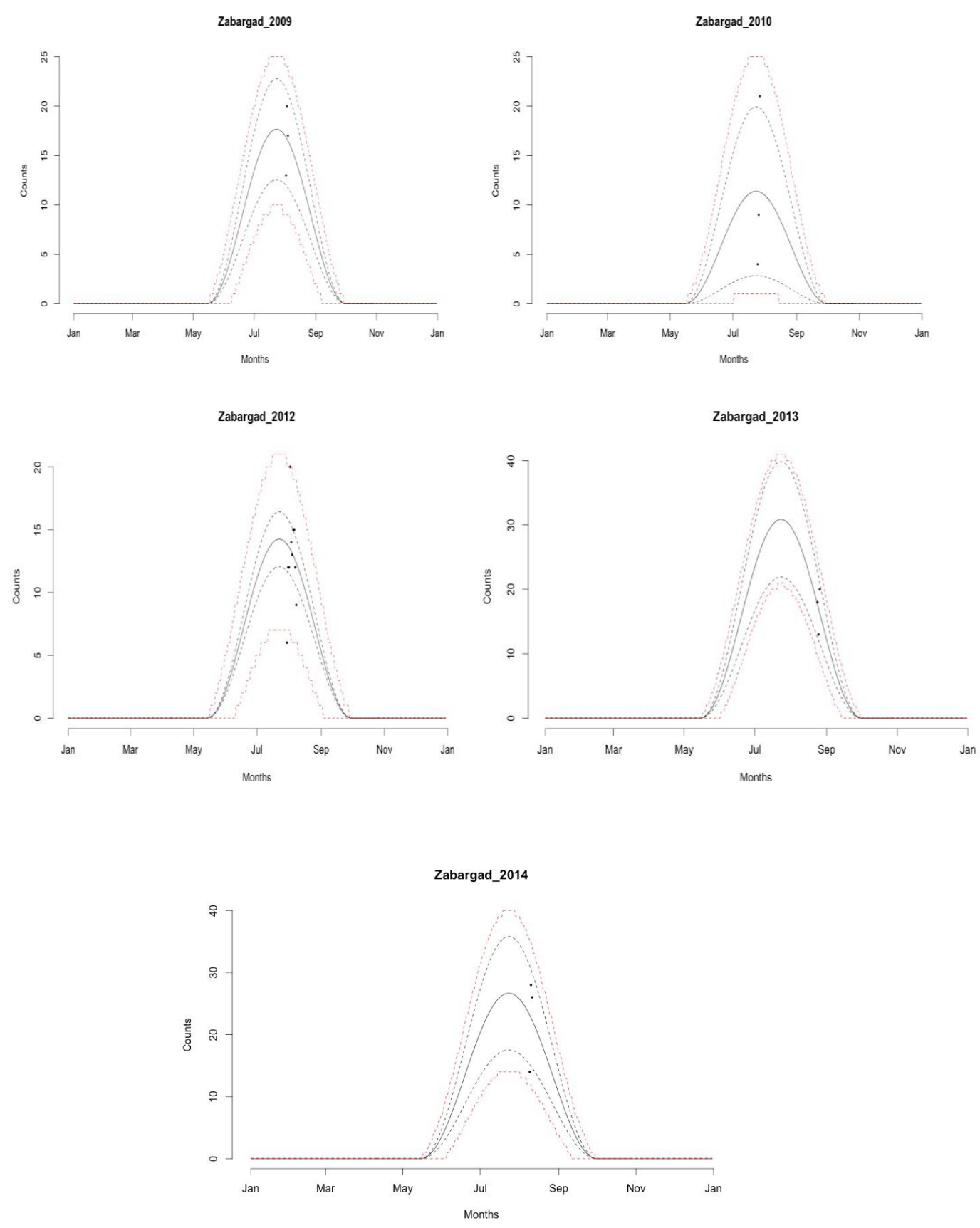

Fig. 4: The nesting peaks on Zabargad Island beaches during the 5 years of the study, estimated based on R software (Giroindot 2012), A) 2009, B) 2010, C) 2012, D) 2013 and E) 2014 
Table (2) gives the percentages of nesting success with years. It is obvious that there was a clear trend of increasing in nesting success percentages with a minimum value of $10 \%$ in 2009 and maximum percentage of $44.1 \%$ in 2014. (Fig. 5).

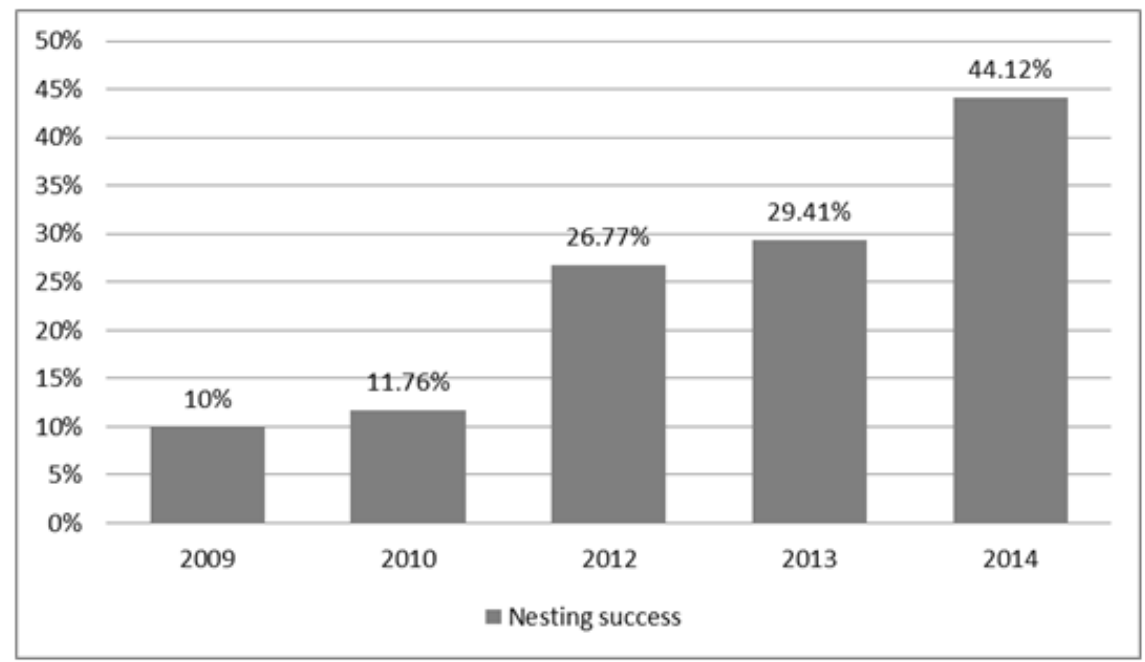

Fig. 5: Calculated annual nesting success as number of nests divided by total number of tracks between 2009 and 2014.

\section{DISCUSSION}

The numbers of estimated annual nest and females in Zabargad island were fluctuated and steadily increased with years to reach the maximum in 2014. The lowest number was recorded in 2010 could be mainly related to the disturbance occurred by the survey team to install 4 satellite tags on 4 nested females during one night out of the 3 nights they spents on the island. This ismight cause disturbace to the nested females and prevent more females to emarge. It is uncertained if the gradual increase in the number of nests with years is uncertained and may be related to the following reasons: conservation effort paid in the last decade, improvement of the survey team preformance and/or reduction of predation potential due to the depletion of shark population (personel communication with fishermen). However, the large fluctuations in the numbers of annual emergencies female turtles are well documented in different turtle species world widei.e loggerhead green turtles (Al-Gheilani, 1996; Limpus et al., 2003; Hanafy, 2012).

Little attention has been paid for green turtles nesting in the Egyptian coast of the Red Sea. The size of the nesting population of green turtles in the Egyptian coast fluctuated between 200 females (Frazier \& Salas 1984, PERSGA 2003) and 175-610 nested females on Zabargad Island during the period between 2001 and 2008 (Hanafy, 2012). In comparison, the present study estimated 37 to 326 females per year on the Zabargad nesting beach during the five years between 2009 and 2014. Steadily increases in the number of nests/night was also recorded where the value estimated in 2014 was duplicated the mean nests/night in 2010.

The main reason for the recorded increase in nesting activities in Zabrgad Island might be related to two main factors or a combination of both; first of all the increase of conservation efforts and public awareness in the Egyptian coast of the Red Sea regarding the importance of marine turtles as a natural resources and a source of income. The efforts of EEAA park rangers in stopping speed boat chasing turtles and tourist touching them might have paid off in the increase of turtle population in the 
Red Sea. Moreover, the increase of coastal development activities along the Red Sea coast might have led to the decrease of sandy beaches available for turtle nesting along the Egyptian coast, leaving Zabargad Island as the only pristine nesting space for green turtles in the Egyptian waters of the Red Sea.

Similarly, nesting success on Zabargad Island between 2009-2014 showed a steadily increases with years. In comparison, Hanafy (2012) found different pattern of flactuations between years during the same period between 2001-2008, without clear trend. The same author estimated the highest recorded nesting success of $33.5 \%$ in 2004. In the present study, the lowest NS\% of $10 \%$ was estimated in 2010, while the highest of $44.1 \%$ was estimated in 2014 . The differences in NS\% between the two studies may be related to the differences in survey method and time of the survey, the nesting season, as also stated by Hanafy (2012). In comparison, the NS\% in the Arabian Gulf was ranging between $60-95 \%$ with an average of $80 \%$, while it was ranging between $30-90 \%$ with an average of about $80 \%$ in RasBairidi, Red Sea Saudi Arabia Coast (Al-Merghani et al., 2000), while it kept different within site in different rockeries around world as it recorded lowest NS\% in Taiwan (20-60\%),(Cheng et al., 2009) , quite increase in Sirilanka 65\% (de Silvia, 1996) and recorded highest NS\% in Tanzania 85\% (Darwall, 1996).

Hanafy (2012) attrebuted these fluctaution to using different methods and time of survey which usually was not conducted during the peak of the nesting season.In this study, the survey trips were selected more carefully to be during the peak of the nesting season (mid of July). In addition, the Model of GIROINDOT (2011) was applied to get the estimation of total tracks.

The fluctuations and propertional increases in annual recorded numbers of nests during the 8 years of Hanafy's study in 2012 and the 5 years of the present study are mainly related to the field survey time of the nesting season or human impact especially on the feeding grounds that spreading in the whole coast of the Red Sea. (Attumet al., 2014). In the present study, it is believed that, beside the two mentioned effects, fluctuations and steady increases in the annual recorded numbers of nests with years may also be related to the more attention paid to the conservation and/or the decreasing of the predation rates on turtle breeders, where clear signs coming from fishermen that mega-shark population decreased sharply during the last two decades (personal communication with local fishermen.

\section{AKNOWLEDGMENT}

I would like to thank all the Boarder of HEPCA (NGO) that funded this study and keep working on supporting conservation of the Red Sea and I would like to thank my colleague in Red Sea Protectorates, the board of Boomerage for earth conservation association

\section{REFERENCES}

Al-Gheilani, H.M.H. (1996). Environmental and biological study on the green turtles in Ras Al-Had region in Sultanate of Oman. MS Thesis, Suez Canal University, Ismalia, Egypt.

Al-Merghani, M.; Miller, J. D.; Pilcher, N. J.; Al-Mansi, A. (2000). The green and hawksbill turtles in the Kingdom of Saudi Arabia: Synopsis of nesting studies 1986-1997. Fauna of Arabia, 18: 369-384.

Anderson, J. (1898). Zoology of Egypt. London, Bernard Quaritch. 
Attum, O.; Kramer, A.; Mahmoud, T. and Fouda, M. (2014). Post-nesting migrations patterns of green turtles (Cheloniamydas) from the Egyptian Red Sea. Zool. Middle East 1-7pp.

Bertram, F. J and Evans, P. G. (1987).Turtles and marine mammals. pp. 288-314. In: Key Environments: Red Sea. Edwards, A. J. and Head, A. M. (eds.). Pergamon Press, Oxford.

Cheng, I.J; Cheng-Ting Huang; Po-Yen Hung ; Bo-ZongKe; Chao-Wei Kuo and Chia-Ling Fong. (2009). Ten Years of Monitoring the Nesting Ecology of the Green Turtle, Cheloniamydas, on Lanyu (Orchid Island), Taiwan. Zoological Studies 48(1): 83-94pp.

Darwall, WRT.(1996). Marine biological and marine resource use surveys in the SongoSongo archipelago, Tanzania. Report no. 3: Simaya Island. The Society for Environmental Exploration and the University of Dar es Salaam.

de Silva, A. (1996). Proposed Action Plan: Conservation, Restoration and Management of the Testudines and their Habitats in Sri Lanka.Department of Wildlife Conservation and Global Environmental Facility Programme.28 pp.

Frazier, J. and Salas, S. (1984). The status of marine turtles in the Egyptian Red Sea. Biol. Conserv. 30(1): 41-67.

Girondot, M.; Delmas, V. and Prévot-Julliard, A. C. (2012). Nouvelesdonnéessur la ponte de la tortue de Floride (Trachemysscriptaelegans) en Île-deFrance. Bulletin de la SociétéHerpétologique de France, 142-143: 71-78.

Godley, B. J.; Blumenthal, J. M.; Broderick, A. C.; Coyne, M. S.; Godfrey, M. H.; Hawkes, L. A., and Witt, M. J. (2008). Satellite tracking of sea turtles: Where have we been and where do we go next. Endangered Species Research, 4: 3-22.

Hanafy, M. H. (2012). Nesting of marine turtles on the Egyptian beaches of the Red Sea.Egyptian Journal of Aquatic Biology \& Fisheries, 16:59- 71.

International Union for the Conservation of Nature (IUCN) (2010).IUCN Red List of Threatened Species.Version 2010.4. 8 December 2010

Limpus, C.J.; Miller, J.D.; Parmenter, C.J. and Limpus, D.J. (2003). The green turtle, Cheloniamydas, population of Raine Island and the northern Great Barrier Reef: 1843-2001. Memoirs-Queensland Museum 49: 349-440.19.

Miller, J.D. (1997). Reproduction in sea turtles. In: Musick, J.A., Lutz, P.L. (Eds.), The Biology of Sea Turtles. CRC Press, Boca Raton, Florida, 51-82 pp.

Musick, J. A., and C. J. Limpus.(1997). Habitat utilization and migration in juvenile sea turtles. Pp. 137-163 in P. L. Lutz and J. A. Musick, eds. The biology of sea turtles.CRC Press, Boca Raton, FL.

Regional Organization for the Conservation of the Environment of the Red Sea Gulf of Aden (PERSGA), (2004).Regional action plan for the conservation of marine turtles and their habitats in the Red Sea and Gulf of Aden.PERSGA Technical Report, Jeddah, Saudi Arabia.

Ross, J. P. and Barwani, M. A. (1982). Review of sea turtles in the Arabian Area. In: Biology and Conservation of Sea Turtles (K. A. Bjorndal, ed.): 373- 382. Smithsonian Institution Press, Washington, D. C.

Rouphael, T.; Abdulla, A.; Attum, O.; Marshall, N., and Ghazali, U. (2013). Do marine protected areas in the Red Sea afford protection to dugongs and sea turtles? Journal of Biodiversity \& Endangered Species, 1, 1-6, doi:10.4172/jbes. 1000102 .

Schroeder, B. and Murphy, S. (1999). Population surveys (ground and aerial) on nesting beaches. In: Eckert, K.L., Bjorndal, K.A., Abreu-Grobois, B.J. Godley

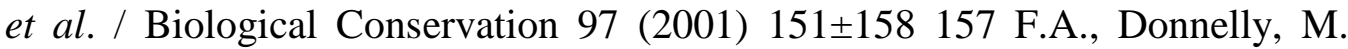


(Eds.), Research and Management Techniques for the Conservation of Sea Turtles. IUCN/SSC Marine Turtle Specialist Group, Washington, DC, Publication No 4. 45 $\pm 55 \mathrm{pp}$.

Seminoff, J.A.; Za'rate, P.; Coyne, M.; Foley, D.G. and Parker, D. (2008).Postnesting migrations of Gala'pagos green turtles Cheloniamydas in relation to oceanographic conditions: integrating satellite telemetry with remotely sensed ocean data. Endanger Species Res 4: 57-72pp.

Seminoff, J., (2002). IUCN Red list global status assessment, green turtle Cheloniamydas. IUCN Marine Turtle Specialist Group Review, 93 pp.

Short, F. T.; Polidoro, B.; Livingstone, S. R.; Carpenter, K. E.; Bandeira, S.; Bujang, J. S. and Zieman, J. C. (2011). Extinction risk assessment of the world's seagrass species. Biological Conservation, 144:1961-1971pp.

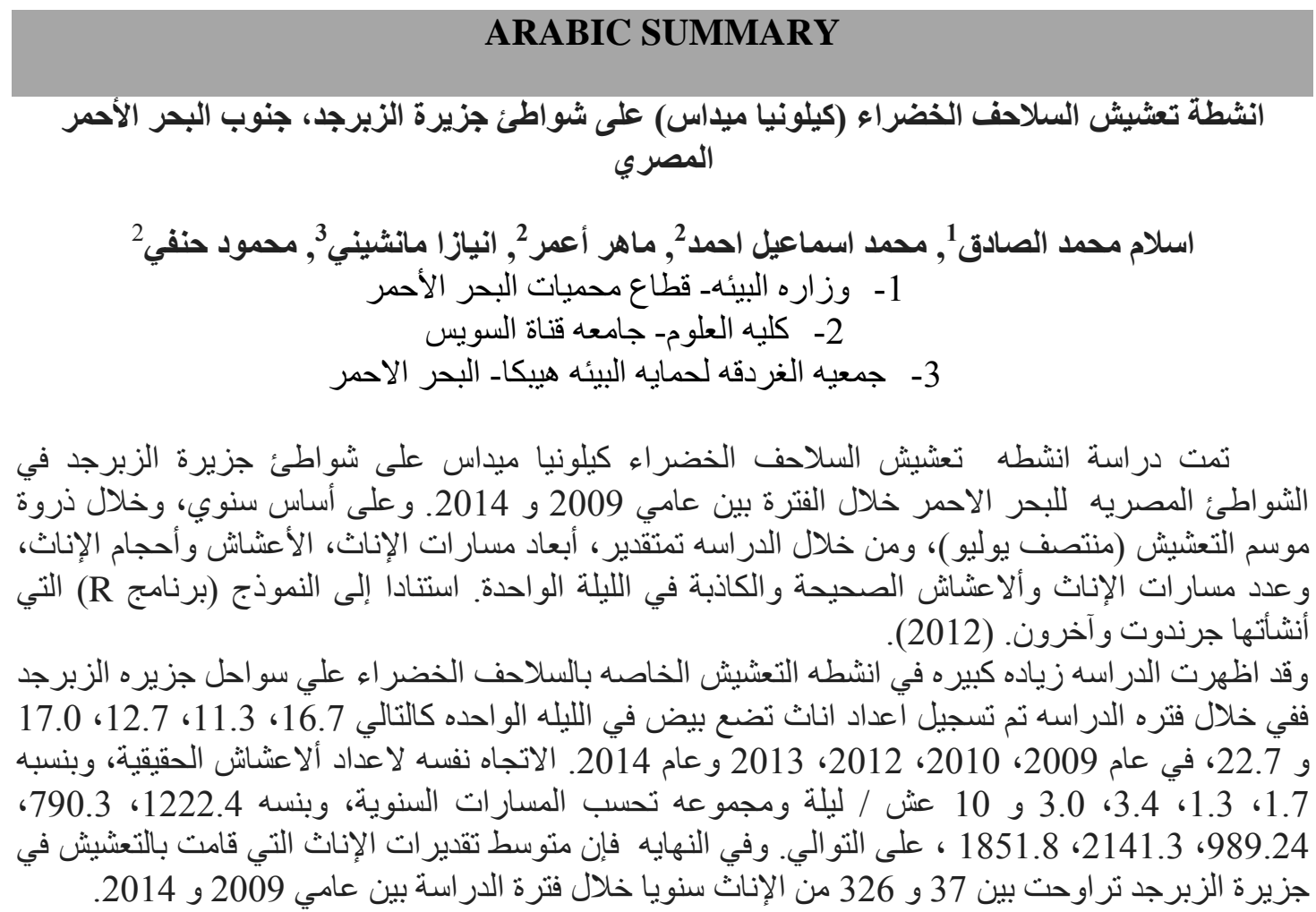

